\title{
Comparisons among old and new provocative tests of GH secretion in 178 normal adults
}

\author{
G Aimaretti, C Baffoni, L DiVito, S Bellone, S Grottoli, M Maccario, E Arvat, F Camanni and E Ghigo \\ Division of Endocrinology, Department of Internal Medicine, University of Turin, Turin, Italy \\ (Correspondence should be addressed to E Ghigo, Divisione di Endocrinologia, Ospedale Molinette, C.so Dogliotti 14, 10126 Torino, Italy; \\ Email: ezio.ghigo@unito.it)
}

\begin{abstract}
Classical provocative stimuli of GH secretion such as insulin-induced hypoglycaemia, arginine, clonidine, glucagon and levodopa have been widely used in clinical practice for approximately 30 years. On the other hand, in the last 10 years new potent stimuli of GH secretion have been proposed, but an extensive comparison with the classical ones has rarely been performed, at least in adults.

In order to compare the GH-releasing activity of old and new provocative stimuli of GH secretion, and to define the normative values of the GH response, in 178 normal adults ( 95 males, 83 females; age range: $20-50$ years, all within $\pm 15 \%$ of their ideal body weight), we studied the GH response to: insulin-induced hypoglycaemia (ITT, $0.1 \mathrm{IU} / \mathrm{kg}$ i.v.), arginine (ARG, $0.5 \mathrm{~g} / \mathrm{kg}$ i.v.), clonidine (CLO, $300 \mu \mathrm{g} / \mathrm{kg}$ p.o.), glucagon (GLU, $1 \mathrm{mg}$ i.m.), pyridostigmine (PD, $120 \mathrm{mg}$ p.o.), galanin (GAL, $80 \mathrm{pmol} / \mathrm{kg}$ per min), GH-releasing hormone (GHRH, $1 \mu \mathrm{g} / \mathrm{kg}$ i.v.), GHRH+ARG, GHRH+PD, hexarelin, a GH-releasing protein (HEX, $2 \mu \mathrm{g} / \mathrm{kg}$ i.v.) and GHRH+HEX $(0.25 \mu \mathrm{g} / \mathrm{kg}$ i.v.). The mean ( \pm s.E.M.) peak GH response to ITT $(21.8 \pm 2.8$, range: $3.0-84.0 \mu \mathrm{g} / \mathrm{l})$ was similar to those to ARG $(18.0 \pm 1.6$, range: $2.9-$ $39.5 \mu \mathrm{g} / \mathrm{l})$ or GLU $(20.5 \pm 2.2$, range: $10.6-36.9 \mu \mathrm{g} / \mathrm{l})$ which, in turn, were higher $(P<0.001)$ than those to CLO $(8.2 \pm 1.6$, range: $0.3-21.5 \mu \mathrm{g} / \mathrm{l})$, PD $(9.6 \pm 1.1$, range: $2.2-33.0 \mu \mathrm{g} / \mathrm{l})$ and GAL $(9.3 \pm 1.1$, range: $3.9-18.3 \mu \mathrm{g} / \mathrm{l})$. The GH response to GHRH $(19.1 \pm 1.5$, range: $2.7-55.0 \mu \mathrm{g} / \mathrm{l})$ was similar to those after ITT, ARG or GLU but clearly lower than those after GHRH+ARG $(65.9 \pm 5.5$, range: $13.8-171.0 \mu \mathrm{g} / \mathrm{l})$ and GHRH+PD $(50.2 \pm 4.6$, range: $17.7-134.5 \mu \mathrm{g} / \mathrm{l})$ which, in turn, were similar. The GH response to HEX (55.3 \pm 5.5 , range: $13.9-163.5 \mu \mathrm{g} / \mathrm{l})$ was similar to those after GHRH+ARG and GHRH+PD but lower $(P<0.001)$ than that after GHRH+HEX $(86.0 \pm 4.3$, range: $49.0-125.0 \mu \mathrm{g} / \mathrm{l})$ which was the most potent stimulus of GH secretion. In this adult population the third centile limits of peak GH response to various stimuli were the following: ITT: 5.3; ARG: 2.9; CLO: 1.5; GLU: 7.6; PD: 2.2; GAL: 4.0; GHRH: 5.0; GHRH+ARG: 17.8; GHRH+PD: 17.9; HEX: 21.6; GHRH+HEX: 57.1 .

These results confirm that, among classical provocative tests of GH secretion, ITT followed by ARG and GLU are the most potent ones and possess clear limits of normality. GHRH+ARG or PD and HEX are strong stimuli of GH secretion which, however, is maximally stimulated by a combination of GHRH and a low dose of HEX. It is recommended that each test is used with appropriate cut-off limits.
\end{abstract}

European Journal of Endocrinology 142 347-352

\section{Introduction}

Classical provocative stimuli of growth hormone $(\mathrm{GH})$ secretion such as insulin-induced hypoglycaemia (ITT), arginine (ARG), clonidine (CLO), glucagon (GLU) and levodopa have been widely used in clinical practice for approximately 30 years $(1-8)$ and the diagnosis of $\mathrm{GH}$ deficiency (GHD) always includes an evaluation of the GH response to provocative testing (9). However, while a normal GH response to provocative testing does not definitively rule out $\mathrm{GH}$ insufficiency in childhood, severe GHD in adults must be demonstrated by provocative tests only (9-13).
Among classical provocative tests, ITT has been considered to be the golden standard test for a number of years, though ARG and GLU are also widely used for the diagnosis of GHD both in childhood and, much more, in adulthood $(9-11,13-18)$.

On the other hand, in the last 10 years new potent stimuli of GH secretion have been proposed. Among them are testing with GH-releasing hormone (GHRH) combined with substances such as pyridostigmine (PD), a cholinergic agonist, and ARG, which markedly potentiate its GH-releasing activity via inhibition of hypothalamic somatostatin release $(12,16,19-21)$. The diagnostic reliability of these tests has been already 
demonstrated $(12,16,19,20,22,23)$. More recently, it has been shown that synthetic peptidyl and nonpeptidyl GH secretagogues possess strong and reproducible GH-releasing activity, particularly in humans (24-27). They act via specific receptors at the pituitary and, mainly, at the hypothalamic level, via mechanisms which, at least partially, are different from those of GHRH (24-28). In fact, GH secretagogues, even at a very low dose, generally show true synergistical interaction with GHRH (29-31). The GH response to this stimulus appears to be one of the most marked ever recorded in humans $(24-31)$.

An extensive comparison between classical and new provocative stimuli of somatotroph secretion in normal adults is still lacking. Thus, the aim of our study was to compare the GH-releasing activity of old and new provocative stimuli of $\mathrm{GH}$ secretion and to define normative values of the $\mathrm{GH}$ response.

\section{Subjects and methods}

One hundred and seventy-eight normal adults (95 males (M), 83 females (F); age range: $20-50$ years, all within $\pm 15 \%$ of their ideal body weight) were studied. The study had been approved by a local, independent ethical committee and all subjects had given their informed consent to participating in the study.

The GH response to the following tests was studied. (a) ITT (0.1 IU/kg i.v.; $n=37 ; 14 \mathrm{M}$, age: $20-42$ years and $23 \mathrm{~F}$, age: $21-48$ years); (b) ARG $(0.5 \mathrm{~g} / \mathrm{kg}$ i.v.; $n=37 ; 15 \mathrm{M}$, age: $23-49$ years and $22 \mathrm{~F}$, age: $24-50$ years); (c) CLO (300 $\mu$ g p.o.; $n=22 ; 10 \mathrm{M}$, age: $25-45$ years and $12 \mathrm{~F}$, age: $20-50$ years); (d) GLU (1 mg i.m.; $n=23 ; 10 \mathrm{M}$, age: $21-45$ years and $13 \mathrm{~F}$, age: $29-35$ years); (e) PD (120 mg p.o.; $n=32 ; 20 \mathrm{M}$, age: $21-38$ years and $12 \mathrm{~F}$, age: 25-36 years); (f) galanin (GAL; $80 \mathrm{pmol} / \mathrm{kg}$ per $\min$ i.v.; $n=16 ; 6 \mathrm{M}$, age: $20-50$ years and $10 \mathrm{~F}$, age: $21-48$ years); (g) GHRH $(1 \mu \mathrm{g} / \mathrm{kg}$ i.v.; $n=57 ; 36$ M, age: $28-45$ years and $21 \mathrm{~F}$, age: $20-48$ years); (h) GHRH+ARG $(n=48 ; 20 \mathrm{M}$, age: $22-40$ years and $28 \mathrm{~F}$, age: 22-35 years); (i) GHRH+PD ( $n=38 ; 14$ M, age: $20-50$ years and $24 \mathrm{~F}$, age: $23-45$ years); (l) hexarelin (HEX; $2 \mu \mathrm{g} / \mathrm{kg}$ i.v.; $n=29 ; 11 \mathrm{M}$, age: $24-46$ years and $18 \mathrm{~F}$, age: $22-45$ years); (m) HEX $(0.25 \mu \mathrm{g} / \mathrm{kg}$ i.v. $)+\mathrm{GHRH}(n=31 ; 20 \mathrm{M}$, age: $22-50$ years and $11 \mathrm{~F}$, age: 22-48 years). Forty subjects underwent at least two different provocative tests (15 M, 25 F, age range: 22-40 years). Specifically, fourteen subjects underwent testing with $\mathrm{PD}$ and GHRH+ARG, nine subjects underwent testing with HEX and GHRH+ARG, eight subjects underwent testing with GHRH+ARG and GHRH+HEX, six subjects underwent testing with ARG alone and GHRH+ARG and three subjects underwent testing with ARG alone and HEX.

All these tests have been performed in the last 2 years and approximately $40 \%$ of them were carried out as part of other study protocols. The tests were performed in the morning starting at 0830-0900 h, after overnight fasting and $30 \mathrm{~min}$ after an indwelling catheter had been placed in an antecubital vein of the forearm kept patent by slow infusion of isotonic saline. Blood samples were taken at baseline and then as follows: (a) every $15 \mathrm{~min}$ up to $90-120 \mathrm{~min}$ after i.v. ITT, ARG, GAL, GHRH, GHRH+ARG, GHRH+PD, HEX and HEX+GHRH test; (b) every $30 \mathrm{~min}$ up to $180 \mathrm{~min}$ after oral CLO and PD; (c) every $30 \mathrm{~min}$ up to $90 \mathrm{~min}$ and then every $15 \mathrm{~min}$ up to $210 \mathrm{~min}$ after i.m. GLU. Serum GH levels $(\mu \mathrm{g} / \mathrm{l})$ were assayed in duplicate at each time-point by IRMA (HGH-CTK, Sorin, Italy). The International Reference Preparation was 80/505 (1 $\mu \mathrm{g} / \mathrm{l}=2 \mathrm{IU})$. All samples from an individual subject were analysed together. The sensitivity of the method was $0.15 \mu \mathrm{g} / \mathrm{l}$. The inter- and intra-assay coefficients of variation were $5.1-7.5 \%$ and $2.6-5.4 \%$ respectively, at $\mathrm{GH}$ levels of 2.9-42.4 and 2.8-41.2 $\mu \mathrm{g} / \mathrm{l}$ respectively.

The results (means \pm S.E.M.) are expressed as maximal peak GH responses. For each test we report the third and the first centile limits of the normal peak GH response in order to clarify which response below normal limits should be considered as low or severely low in patients suspected of GHD.

Statistical analysis of the data was performed by multiple ANOVA and non-parametric Kruskall-Wallis test.

\section{Results}

The mean ( \pm s.E.M.) peak GH response to ITT $(21.8 \pm 2.8$, range: $3.0-84.0 \mu \mathrm{g} / \mathrm{l})$ was similar to those to ARG (18.0 \pm 1.6 , range: $2.9-39.5 \mu \mathrm{g} / \mathrm{l})$ or GLU $(20.5 \pm 2.2$, range: $10.6-36.9 \mu \mathrm{g} / \mathrm{l})$ which, in turn, were higher $(P<0.001)$ than those to CLO $(8.2 \pm 1.6$, range: $0.3-$ $21.5 \mu \mathrm{g} / \mathrm{l}), \mathrm{PD}(9.6 \pm 1.1$, range: $2.2-33.0 \mu \mathrm{g} / \mathrm{l})$ and GAL $(9.3 \pm 1.1$, range: $3.9-18.3 \mu \mathrm{g} / \mathrm{l})$ (Fig. 1$)$.

The GH response to GHRH $(19.1 \pm 1.5$, range: $2.7-$ $55.0 \mu \mathrm{g} / \mathrm{l})$ was similar to those after ITT, ARG or GLU but clearly lower than those after GHRH+ARG $(65.9 \pm 5.5$, range: $13.8-171.0 \mu \mathrm{g} / \mathrm{l})$ and GHRH+PD (50.2 \pm 4.6 , range: $17.7-134.5 \mu \mathrm{g} / \mathrm{l}$ ) which, in turn, were similar (Fig. 1).

The GH response to HEX (55.3 \pm 5.5 , range: $13.9-$ $163.5 \mu \mathrm{g} / \mathrm{l})$ was similar to those after GHRH+ARG and GHRH+PD (Fig. 1).

The combined administration of GHRH+HEX elicited the highest GH peak response $(86.0 \pm 4.3$, range: $49.0-$ $125.0 \mu \mathrm{g} / \mathrm{l} ; \mathrm{P}<0.001$ vs GHRH+ARG and GHRH+PD) (Fig. 1).

The third centile normative limits of the peak GH response to various stimuli were the following: ITT: 5.3; ARG: 2.9; CLO: 1.5; GLU: 7.6; PD: 2.2; GAL: 4.0; GHRH: 5.0; GHRH+ARG: 17.8; GHRH+PD: 17.9; HEX: 21.6; GHRH+HEX: 57.1 (Table 1).

On the other hand, the first centile normative limits of the peak GH response were the following: ITT: 3.8; ARG: 2.7; CLO: 1.3; GLU: 7.1; PD: 2.1; GAL: 3.9; GHRH: 3.8; 


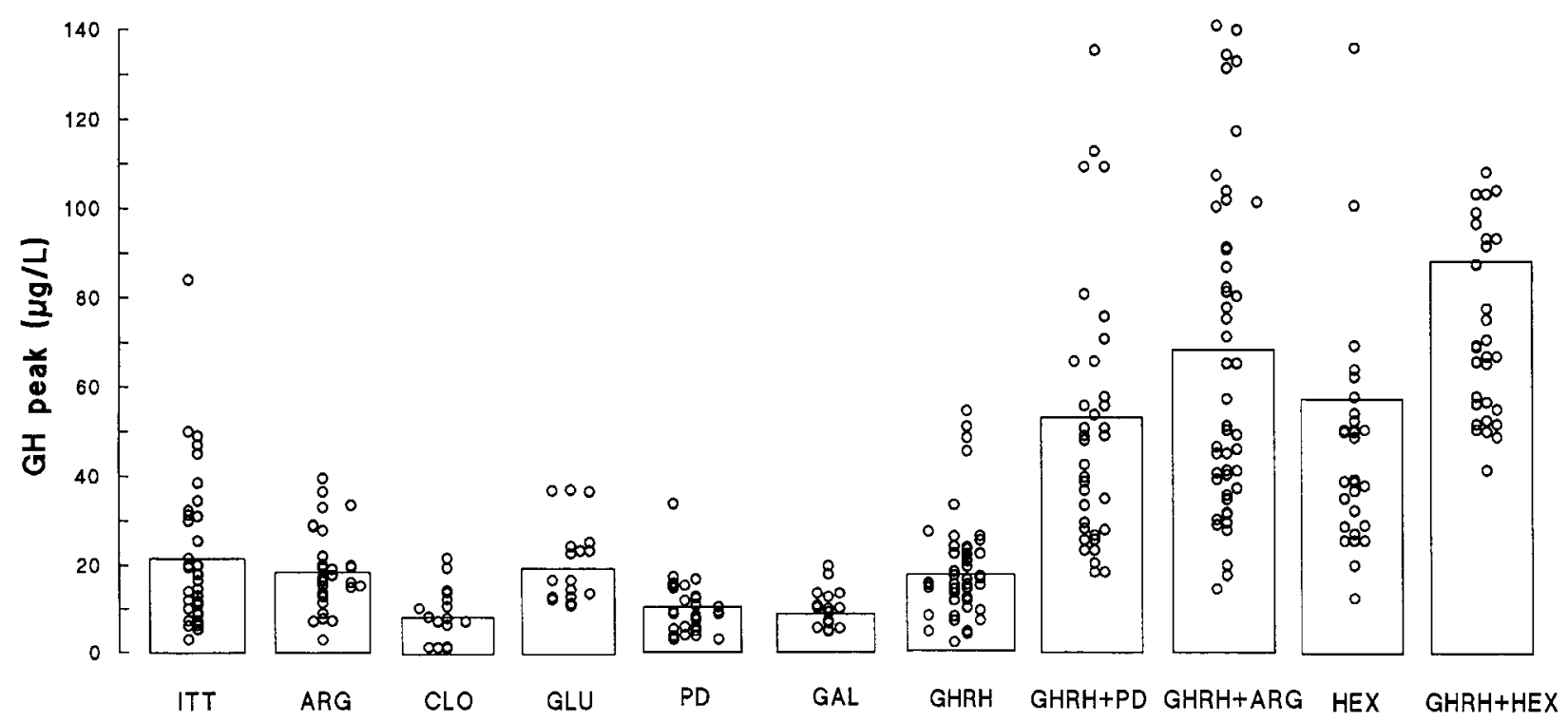

Figure 1 Mean and individual peak GH responses to classical stimuli, GHRH, GHRH+PD, GHRH+ARG, HEX and GHRH+HEX in normal adult subjects.

\section{GHRH+ARG: 15.2; GHRH+PD: 17.7; HEX: 16.5; Side-effects}

GHRH+HEX: $51.7 \mu \mathrm{g} / \mathrm{l}$ (Table 1).

The mean GH peaks to ITT, CLO, GLU, PD, GAL, GHRH, GHRH+PD, HEX and GHRH+HEX were similar in both sexes. On the other hand, the $\mathrm{GH}$ responses to ARG and GHRH+ARG were significantly higher in women than in men (ARG: $22.1 \pm 2.3$ vs $15.3 \pm 1.3 \mu \mathrm{g} /$ l, $P<0.03$; GHRH+ARG: $80.3 \pm 1.8$ vs $64.5 \pm 2.1$, $P<0.01$ respectively).
ITT caused characteristic hypoglycaemic symptoms. ARG and GLU induced vomiting in 2 and $15 \%$ of subjects respectively. PD induced transient abdominal pain and/or muscle fasciculation in approximately $40 \%$ of the subjects. CLO induced mild somnolence in 35\% of subjects, GAL infusion a bitter taste in all subjects, GHRH a transient facial flushing in $40 \%$ of subjects,

Table 1 Mean ( \pm S.E.M.), range, 3rd and 1st centile limits of the peak GH responses to various provocative stimuli in normal adults.

\begin{tabular}{|c|c|c|c|c|}
\hline & $\begin{array}{c}\text { Mean }( \pm \text { S.E.M. }) \\
(\mu \mathrm{g} / \mathrm{l})\end{array}$ & $\begin{array}{l}\text { Range } \\
(\mu \mathrm{g} / \mathrm{l})\end{array}$ & $\begin{array}{l}\text { 3rd centile } \\
\quad(\mu \mathrm{g} / \mathrm{l})\end{array}$ & $\begin{array}{c}\text { 1st centile } \\
(\mu \mathrm{g} / \mathrm{l})\end{array}$ \\
\hline $\begin{array}{l}\text { ITT } \\
(0.1 \mathrm{IU} / \mathrm{kg} \text { i.v.; } n=37)\end{array}$ & $21.8 \pm 2.8$ & $3.0-84.0$ & 5.3 & 3.8 \\
\hline $\begin{array}{l}\text { ARG } \\
(0.5 \mathrm{~g} / \mathrm{kg} \text { i.v.; } n=37)\end{array}$ & $18.0 \pm 1.6$ & $2.9-39.5$ & 2.9 & 2.7 \\
\hline $\begin{array}{l}\text { CLO } \\
(300 \mu \mathrm{g} / \mathrm{kg} \text { p.o.; } n=22)\end{array}$ & $8.2 \pm 1.6$ & $0.3-21.5$ & 1.5 & 1.3 \\
\hline $\begin{array}{l}\text { GLU } \\
1 \mathrm{mg} \text { i.m.; } n=23 \text { ) }\end{array}$ & $20.5 \pm 2.2$ & $10.6-36.9$ & 7.6 & 7.1 \\
\hline $\begin{array}{l}\text { PD } \\
(120 \mathrm{mg} \text { p.o.; } n=32)\end{array}$ & $9.6 \pm 1.1$ & $2.2-33.0$ & 2.2 & 2.1 \\
\hline $\begin{array}{l}\mathrm{GAL} \\
(80 \mathrm{pmol} / \mathrm{kg} \text { per } \min ; n=16)\end{array}$ & $9.3 \pm 1.1$ & $3.9-18.3$ & 4.0 & 3.9 \\
\hline $\begin{array}{l}\text { GHRH } \\
(1 \mu \mathrm{g} / \mathrm{kg} \text { i.v.; } n=57)\end{array}$ & $19.1 \pm 1.5$ & $2.7-55.0$ & 5.0 & 3.8 \\
\hline $\begin{array}{l}\text { GHRH+ARG } \\
(n=48)\end{array}$ & $65.9 \pm 5.5$ & $13.8-171.0$ & 17.8 & 15.2 \\
\hline $\begin{array}{l}\text { GHRH }+\mathrm{PD} \\
(n=38)\end{array}$ & $50.2 \pm 4.6$ & $17.7-134.5$ & 17.9 & 17.7 \\
\hline $\begin{array}{l}\text { HEX } \\
(2.0 \mu \mathrm{g} / \mathrm{kg} ; n=29)\end{array}$ & $55.3 \pm 5.5$ & $13.9-163.5$ & 21.6 & 16.5 \\
\hline $\begin{array}{l}\text { GHRH + HEX } \\
(\mathrm{HEX}, 0.25 \mu \mathrm{g} / \mathrm{kg} ; n=31)\end{array}$ & $86.0 \pm 4.3$ & $49.0-125.0$ & 57.1 & 51.7 \\
\hline
\end{tabular}


both when given alone and combined with PD, ARG or HEX. HEX alone caused transient facial flushing in 20\% of subjects.

\section{Discussion}

In the present study, the GH responses to several old and new provocative tests in normal adults were compared in order to define the normative values of somatotroph response. The present results confirm that, among classical provocative tests of GH secretion, ITT followed by ARG and GLU are the most potent ones and possess clear limits of normality. Among non-classical provocative tests, GHRH+ARG or PD and HEX are strong stimuli of GH secretion which, however, is maximally stimulated by the combination of GHRH and low-dose HEX. The remarkable differences in the GH-releasing activities of the various tests leads to impressive differences among normative values of somatotroph responsiveness.

GH secretion in humans can be stimulated by physiological and pharmacological stimuli (9, 32-34). Physical exercise, fasting and sleep are the most recognised physiological stimuli of somatotroph secretion but are generally not used as diagnostic tools because their value is reduced by low potency, the most marked intra-individual variability and/or low compliance $(9,32)$. Among the notable pharmacological stimuli, the majority of them have been addressed in the present study; a notable exception being L-dopa; however, it has already been demonstrated that its GH-releasing activity in normal adults is clearly lower than that of ITT and is associated with frequent sideeffects (4).

Classical and some non-classical stimuli of GH secretion, i.e. ITT, ARG, CLO, PD and GAL, act via central mechanisms involving the stimulation of GHRH-secreting neurones and/or inhibition of hypothalamic somatostatin release $(33,35)$. GLU releases GH only after intramuscular and subcutaneous but not intravenous administration, via mechanisms still unknown $(26,36)$.

GHRH, the specific stimulatory neurohormone, stimulates GH synthesis and release from somatotrophs and its action is under the fluctuating inhibitory effect of somatostatin $(33,37)$. In fact, substances such as ARG and PD which act via the inhibition of hypothalamic somatostatin release $(21,33,35,38-40)$ strongly potentiate the GH-releasing activity of GHRH reducing the intra-individual variability of somatotroph responsiveness to the neurohormone alone $(22,37)$.

On the other hand, GH-releasing peptides (GHRPs) such as HEX possess strong and reproducible GHreleasing activity in humans and truly synergise with GHRH even when given at low dose (24-28). They act on specific receptors at the pituitary, mainly at the hypothalamic level, probably antagonising somatostatin activity and increasing the activity of GHRHsecreting neurones $(24-31)$.
In agreement with other data in normal adults, our results confirm that ITT is the most potent provocative test of GH secretion and that ARG and GLU are good classical alternatives $(7,10,11,13-17,41,42)$.

For each test studied, we have reported the third and the first centile limits of the normal peak GH response, in order to clarify which response below normal limits should be considered as low or severely low in patients suspected of GHD, at least in our laboratory.

Indeed, normative values of the $\mathrm{GH}$ response to these stimuli overlap with those reported by other authors (7, $10,41,42)$. In fact, the third and first centile limits of normal response to ITT were 5 and $3 \mu \mathrm{g} / \mathrm{l}$ respectively, the last one being the limit below which severe GHD is demonstrated by ITT $(11,13)$. Meanwhile, our data confirm that CLO as well as PD and GAL are not good tests with which to evaluate somatotroph response in normal subjects $(7,9,21,33,41,43)$.

Our data again confirm that testing with GHRH alone has low value as a provocative test $(9,12,19,21,37)$. In fact, the mean $\mathrm{GH}$ response to GHRH was not significantly higher than that elicited by ITT and showed absent GH responses in some normal adults.

That the somatotroph responsiveness to GHRH is strongly potentiated by $\mathrm{PD}$ and ARG is well recognised $(18,20,21,29,39,40)$. In fact, testing with GHRH+PD or ARG has already been shown to be one of the most potent stimuli of GH secretion in normal children (16) and the present data confirm this evidence in adults (12, $19,20,23)$. These tests also show good reproducibility $(19,22)$ and their GH-releasing activity is approximately threefold higher than that of ITT $(16,19,23$ and present study). In fact, they have been already proposed as the best alternatives to ITT for the diagnosis of GHD in adults, provided that appropriate cut-off limits are assumed $(9,13,18,19,21-23)$.

The strong GH-releasing activity of GHRPs is again confirmed by the present results. In fact HEX alone shows a stimulatory effect of GH secretion as marked as GHRH+PD or ARG. On the other hand, the combined administration of GHRH and HEX, even given at low dose, really represents the most potent stimulus of somatotroph secretion in normal adults, being approximately fourfold more potent than ITT.

In all, this evidence strengthens once more the suggestion that the maximal secretory capacity of the somatotroph cell in normal humans is far greater than that previously thought, and further indicates that normative reference values of $\mathrm{GH}$ response must be appropriate to the potency of each stimulus $(13,23)$. When looking for alternatives to ITT as provocative tests for the diagnosis of GHD, one should not necessarily ask for the most potent test but for a potent and reproducible test without side-effects. Indeed, HEX alone and combined with GHRH as well as GHRH+PD or ARG possess these advantages $(29,31,44)$. It is probable that testing including GHRH administration directly explores the pituitary GH-releasable pool, while 
testing with a GHRP alone explores more the integrity of hypothalamic mechanisms involved in the control of somatotroph function. The usefulness of this subtle distinction remains to be verified from a clinical point of view.

It must be emphasised that the $\mathrm{GH}$ response to various provocative stimuli was generally independent of gender, a notable exception being that to ARG alone or combined with GHRH. The peculiar enhancing effect of oestrogens on the stimulatory effect of ARG on somatotroph secretion had been already shown (45) and our present data agree with this evidence.

In conclusion, this study first compared the $\mathrm{GH}_{-}$ releasing activity of old and new provocative tests of $\mathrm{GH}$ secretion in adults between 20 and 50 years of age. ITT followed by ARG and GLU are the most potent classical provocative tests but new tests such as GHRH+ARG, GHRH+PD, HEX alone and, above all, low-dose HEX+GHRH are much more potent and show more clear normative values. It is recommended that each test is used with appropriate cut-off limits and we believe that having a high limit of the lowest normal GH response to a provocative test probably allows for better evaluation of insufficient GH responses. However, following the guidelines of the recent GH Research Society consensus (13), it is suggested that normative values are defined in each laboratory employing the same GH assay. In fact, the variability between different assay methods is remarkable and could affect the interpretation of the results (46).

\section{Acknowledgements}

This study was supported by MURST (grant no. 9706151106 from Rome, Italy) and Fondazione per lo Studio delle Malattie Endocrino-Metaboliche, Turin, Italy. The authors wish to thank Dr G Corneli, C Origlia and L Quaranta for their participation in the study and Mrs M Talliano for her skilful technical assistance.

\section{References}

1 Cain JP, Williams GH \& Dluhy RG. Glucagon-initiated human growth hormone release: a comparative study. Canadian Medical Association Journal 1972107 617-622.

2 Eddy RL, Gilliland PF, Ibarra JD, McMurry JF \& Thompson JQ. Human growth hormone release: comparison of provocative test procedures. American Journal of Medicine 197456 179-185.

3 Lin T \& Tucci JR. Provocative tests of growth hormone release. A comparison of results with seven stimuli. Annals of Internal Medicine $197480464-469$.

4 Sutton J \& Lazarus L. Growth hormone in exercise: comparison of physiological and pharmacological stimuli. Journal of Applied Physiology 197641 523-527.

5 Tapanainen P, Knip M, Lautala P \& Leppalluoto J. Variable plasma growth hormone (GH)-releasing hormone and $\mathrm{GH}$ responses to clonidine, L-dopa and insulin in normal men. Journal of Clinical Endocrinology and Metabolism 198867 845-849.

6 Kopperschaar HPF, Ten Horn CD, Thijssen JHH, Page MD, Dieguez C \& Scanlon MF. Differential effect of arginine on growth hormone releasing hormone and insulin induced growth hormone secretion. Clinical Endocrinology 199236 487-490.
7 Rahim A, Toogood AA \& Shalet SM. The assessment of growth hormone in normal young adult using a variety of provocative agents. Clinical Endocrinology 199645 557-562.

8 Vahl N, Jorgensen JOL, Jurik AG \& Christiansen JS. Abdominal adiposity and physical fitness are major determinants of the age associated decline in stimulated GH secretion in healthy adults. Journal of Clinical Endocrinology and Metabolism 199681 22092215.

9 Shalet SM, Toogood A, Rahim A \& Brennan BM. The diagnosis of growth hormone deficiency in children and adults. Endocrine Reviews 199819 203-223.

10 Hoffman DM, O'Sullivan AJ, Baxter RC \& Ho KY. Diagnosis of growth hormone deficiency in adults. Lancet $19943431064-$ 1068.

11 Thorner MO, Bengtsson BA, Ho KKY, Albertsson-Wikland K, Christiansen JS, Faglia G et al. Diagnosis of growth hormone deficiency in adults. Journal of Clinical Endocrinology and Metabolism 199580 3097-3098.

12 Ghigo E, Aimaretti G, Gianotti L, Bellone J, Arvat E \& Camanni F. New approach to the diagnosis of growth hormone deficiency in adults. European Journal of Endocrinology 1996134 352-355.

13 Growth Hormone Research Society (GRS). Consensus guidelines for the diagnosis and treatment of adults with GH deficiency. Statement of the GRS workshop on adult GHD. Journal of Clinical Endocrinology and Metabolism 199883 379-381.

14 Jones SL, Trainer PJ, Perry L, Wass JAH, Besser GM \& Grossman A. An audit of the insulin tolerance test in adult subjects in an acute investigation unit over one year. Clinical Endocrinology 199441 123-128.

15 De Boer H, Blok G \& van der Veen EA. Clinical aspects of growth hormone deficiency in adults. Endocrine Reviews 199516 63-86.

16 Ghigo E, Bellone J, Aimaretti G, Bellone S, Loche S, Cappa M et al. Reliability of provocative tests to assess growth hormone secretory status. Study in 472 normally growing children. Journal of Clinical Endocrinology and Metabolism 199681 3323-3327.

17 Svensson J, Johannsson G \& Bengtsson BA. Insulin-like growth factor-I in growth hormone-deficient adults: relationship to population-based normal value, body composition and insulin tolerance test. Clinical Endocrinology 199746 579-586.

18 Ghigo E, Aimaretti G, Corneli G, Bellone J, Arvat E, Maccario M et al. Diagnosis of GH deficiency in adults. Growth Hormone and IGF Research 19988 55-58.

19 Andersen M, Hansen TT, Stoving RK, Bertelsen J, Hangaard J, Hyltoft Petersen $\mathrm{P}$ et al. The pyridostigmine-growth-hormonereleasing hormone test in adults. The reference interval and a comparison with the insulin tolerance test. Endocrinology and Metabolism 19963 197-206.

20 Longobardi S, Merola B, Pivonello R, Di Rella F, Di Somma C, Colao A et al. Re-evaluation of growth-hormone (GH) secretion in 69 adults diagnosed as GH-deficient patients during childhood. Journal of Clinical Endocrinology and Metabolism 199681 12441247.

21 Ghigo E, Arvat E, Aimaretti G, Broglio F, Giordano R \& Camanni F. Diagnostic and therapeutic uses of growth hormone-releasing substances in adult and elderly subjects. Baillieres Clinical Endocrinology and Metabolism 199812 341-358.

22 Valetto MR, Bellone J, Baffoni C, Savio P, Aimaretti G, Gianotti L et al. Reproducibility of the growth hormone response to stimulation with growth hormone releasing hormone plus arginine during lifespan. European Journal of Endocrinology 1996135 135-138.

23 Aimaretti G, Corneli G, Razzore P, Bellone S, Baffoni C, Arvat E et al. Comparison between insulin-induced hypoglycemia and growth hormone $(\mathrm{GH})$-releasing hormone+arginine as provocative tests for the diagnosis of GH deficiency in adults. Journal of Clinical Endocrinology and Metabolism 199883 1615-1618.

24 Bowers CY. GH releasing peptides. Structure and kinetics. Journal of Pediatric Endocrinology 19936 21-31.

25 Smith RG, Cheng K, Schoen WR, Pong SS, Hickey G, Jacks T et al. A nonpeptidyl growth hormone secretagogue. Science 1993260 1640-1643. 
26 Ghigo E, Arvat E, Gianotti L, Imbimbo BP, Leanerts V \& Deghengh R. Growth hormone-releasing activity of hexarelin, a new synthetic hexapeptide, after intravenous, subcutaneous, intranasal and oral administration in man. Journal of Clinical Endocrinology and Metabolism 1994 78 693-698.

27 Casanueva FF \& Dieguez C. Growth hormone secretagogues physiological role and clinical utility. Trends in Endocrinology and Metabolism 199910 30-38.

28 Papovic V, Damjanovic S, Micic D, Djurovic M, Dieguez C \& Casanueva FF. Blocked growth hormone-releasing peptide (GHRP-6)-induced GH secretion and absence of the synergic action of GHRP-6 plus GH-releasing hormone in patients with hypothalamo-pituitary disconnection: evidence that GHRP-6 main action is exerted at the hypothalamic level. Journal of Clinical Endocrinology and Metabolism 199580 942-947.

29 Arvat E, Gianotti L, Di Vito L, Imbimbo BP, Lenaerts V, Deghenghi $\mathrm{R}$ et al. Modulation of growth hormone-releasing activity of hexarelin in man. Neuroendocrinology 199561 51-56.

30 Massoud AF, Hindmarsh PC \& Brook CG. Hexarelin-induced growth hormone, cortisol, and prolactin release: a dose-response study. Journal of Clinical Endocrinology and Metabolism 199681 4338-4341.

31 Gasperi M, Aimaretti G, Scarcello S, Corneli G, Cosci C, Arvat E et al. Low dose hexarelin+GHRH as diagnostic tool for the diagnosis of GH deficiency (GHD) in adults. Comparison with insulininduced hypoglycaemia test. Journal of Clinical Endocrinology and Metabolism 2000 (In Press).

32 Frasier SD. A review of growth hormone stimulation tests in children. Pediatrics 197453 929-936.

33 Ghigo E. Neurotransmitter control of growth hormone secretion. In Regulation of Growth Hormone and Somatic Growth, pp 103136. Ed LF De la Cruz. Amsterdam: Elsevier Science Publishers, 1992.

34 Underwood LE \& Van Wyk JJ. Normal and aberrant growth. In Williams Textbook of Endocrinology, pp 1079-1138. Eds JD Wilson \& DW Foster. Philadelphia: Saunders, 1992.

35 Muller EE \& Nistico' G. Brain Messengers and the Pituitary. San Diego: Academic Press, 1989.

36 Cain JP, Gordon HW \& Dluhy RG. Glucagon stimulation of human growth hormone. Journal of Clinical Endocrinology 197031222 225.

37 Mazza E, Ghigo E, Goffi S, Procopio M, Imperiale E, Arvat E et al. Effect of the potentation of the cholinergic activity on the variability in individual GH response to GH-releasing hormone. Journal of Endocrinological Investigation 198912 795-800.

38 Massara F, Ghigo E, Demislis K, Tongolo D, Mazza E, Locatelli V et al. Cholinergic involvement in the growth hormone releasing hormone induced growth hormone release. Studies in normal and acromegalic subjects. Neuroendocrinology 198643 670675.

39 Alba-Roth J, Muller OA, Schopol J \& Von Werder K. Arginine stimulates growth hormone secretion by suppressing endogenous somatostatin secretion. Journal of Clinical Endocrinology and Metabolism 198867 1186-1189.

40 Penalva A, Muruais C, Casanueva FF \& Dieguez C. Effect of enhancement of endogenous cholinergic tone with pyridostigmine on the dose-response relationships of growth hormone (GH)-releasing hormone induced GH secretion in normal subjects. Journal of Endocrinology and Metabolism 199070 324-327.

41 Baum HBA, Biller BMK, Katzmelson J, Oppenheim DS, Clemmons $\mathrm{DR}$, Cannistraro KB et al. Assessment of growth hormone (GH) secretion in men with adult-onset $\mathrm{GH}$ deficiency with that in normal men: a clinical research study. Journal of Clinical Endocrinology and Metabolism 199681 84-92.

42 Fisker S, Jorgensen JO, Orskov H \& Christiansen JS. GH stimulation tests: evaluation of GH responses to heat test versus insulin tolerance test. European Journal of Endocrinology 1998139 605-610.

43 Hoeck HC, Jakobsen PE, Vestergaard P, Falhof J \& Laurberg P. Differences in reproducibility and peak growth hormone responses to repeated testing with various stimulators in healthy adults. Growth Hormone and IGF Research 1999 9 18-24.

44 Ghigo E, Arvat E, Muccioli G \& Camanni F. Growth hormonereleasing peptides. European Journal of Endocrinology 1997136 445-460.

45 Merimee TJ, Fineberg SE \& Tysan JE. Fluctuations of human growth hormone secretion during menstrual cycle: response to arginine. Metabolism 199618 606-608.

46 Strasburger CJ \& Dottani MT. New growth hormone assay: potential benefits. Acta Paediatrica Scandinavica Supplementum 1997423 5-11.

Received 7 July 1999

Accepted 3 December 1999 